\title{
Elastisitas Permintaan Produk Tembakau di Indonesia: Studi Konsumsi Rokok Lintas Rumah Tangga
}

\author{
Mohtar Rasyid*) \\ Jurusan Ekonomi Pembangunan \\ Fakultas Ekonomi dan Bisnis Universitas Trunojoyo Madura
}

\begin{abstract}
ABSTRAK
Di tengah kesulitan pemerintah untuk menemukan sumber penerimaan negara, wacana kenaikan cukai ini memang merupakan opsi yang bisa diterima. Akan tetapi, pihak industri tentu tidak akan tinggal diam menyikapi isu ini. Dengan latar belakang tersebut, paper ini bertujuan untuk menganalisis efek kuantitatif perubahan cukai terhadap permintaan rokok sekaligus implikasinya terhadap penerimaan negara. Data yang digunakan adalah hasil survei Indonesia Family Life Survey (IFLS) rilis terbaru (2014) yang menyediakan seksi khusus mengenai kebiasaan merokok. Menggunakan model estimasi permintaan myopic, riset ini menghasilkan beberapa temuan penting. Pertama, respon permintaan rokok terhadap cukai ternyata asimetris. Untuk kelas cukai yang berbeda, dihasilkan estimasi elastisitas harga yang berbeda pula. Kedua, sebagai konsekwensi dari temuan sebelumnya, efek kenaikan rokok terhadap penerimaan cukai juga tidak linear. Kenaikan cukai tidak selalu berimplikasi pada penurunan penerimaan secara tajam. Tipe rokok dengan level harga yang relatif mahal, relatif memiliki jenis permintaan yang relatif inelastik. Kenaikan harga cukai rokok pada segmen pasar kelas ini tidak banyak mengurangi permintaan.
\end{abstract}

Kata kunci: Elastisitas Asimetri, Cukai Rokok, Penerimaan Negara, Data Mikro

\section{Elasticity of Demand for Tobacco Products in Indonesia: Cross-Household Consumption Study}

\begin{abstract}
In the midst of government difficulties to find sources of state revenues, the discourse on excise increases is indeed an acceptable option. However, the industry certainly will not stay silent to address this issue. Base on this background, this paper aims to analyze the quantitative effects of tax change on cigarette demand as well as its implications for state revenues. The data used are the latest Indonesian Family Life Survey (IFLS) survey results (2014) that provide a special section on smoking habits. Using myopic request estimation model, this research yielded some important findings. First, the response of demand for cigarettes to excise was asymmetric. For different excise class, different price elasticity estimates are generated. Secondly, as a consequence of previous findings, the effect of cigarette increases on tax revenue is also not linear. Excise increases do not necessarily imply a sharp decline in revenue. Type of cigarettes with relatively high price levels; relatively have relatively inelastic demand type. The increase in cigarette excise prices in this segment of the class market does not significantly reduce demand.
\end{abstract}

Keywords: elasticity, cigarette taxes, govermnent revenue, micro data

\section{PENDAHULUAN}

Indonesia dikenal sebagai salah satu negara dengan jumlah perokok aktif tertinggi di dunia (dibawah China dan India). Di kawasan ASEAN, prevalensi merokok usia dewasa di Indonesia hingga saat ini masih menjadi nomor satu (SEATCA, 2014). Tingginya prevalensi merokok ini kemungkinan berasosiasi dengan relatif murahnya harga rokok di Indonesia dibandingkan negara lain (ITIC, 2013). Rokok hampir selalu menjadi kontroversi. Mengingat alasan kesehatan, laju industri rokok dibatasi dengan berbagai regulasi mulai kemasan, pemasaran, kandungan hingga ketentuan larangan merokok di beberapa tempat (periklanan). Batasan merokok juga berupa kuota produksi yang dilekatkan melalaui mekanisme 
cukai. Sungguhpun demikian, permintaan rokok relatif stabil. Walhasil, produk dengan cap "membunuh" ini masih bisa menyumbang lebih dari Rp100 Triliun dari penerimaan cukai 2014. Artinya, harga yang tinggi tidak banyak menggeser permintaan. Penerimaan negara dari cukai rokok menunjukkan kecenderungan naik dari tahun ke tahun. Pada tahun 2010 tercatat penerimaan negara dari cukai rokok sebesar 64 triliun rupiah, naik menjadi 68 triliun rupiah pada tahun 2011, dan 80 triliun rupiah pada tahun 2012. Pada akhir tahun 2014 diperkirakan penerimaan cukai rokok diatas 100 triliun rupiah. Besarnya penerimaan cukai, mendorong aksi penggunaan cukai rokok secara ilegal. Survei cukai rokok yang dilakukan oleh Pusat Studi Ekonomi dan Kebijakan Publik (PSEKP) UGM (2014) melaporkan bahwa nilai pelanggaran cukai rokok selama periode riset 2008 - 2014 mencapai sekitar 0,5 persen sampai 0,9 persen dari nilai penerimaan cukai. Meski secara prosentase kerugian ini relatif kecil, namun secara total nilai kerugian negara ini tentunya cukup signifikan.

Selain menggunakan piranti kebijakan pembatasan berbasis harga (cukai), negara juga membatasi peredaran rokok melalui aturan yang sangat ketat dalam kemasan produk rokok. Peraturan Pemerintah RI Nomor 109 tahun 2012 tentang "Pengamanan Bahan yang Mengandung Zat Adiktif Berupa Produk Tembakau" secara jelas menyebutkan dalam Pasal 24 ayat (1), yakni: setiap produsen dilarang untuk mencantumkan keterangan atau tanda apapun yang menyesatkan atau kata-kata yang bersifat promotif. Dalam pasal 24 ayat (2) dijelaskan bahwa selain pelanggaran sebagimana dimaksud pada ayat (1), setiap produsen dilarang mencantumkan kata "light", "ultra light", "mild", "extra mild", "low tar", "slim", "special", "fullflavor", "premium" atau kata lain yang mengindikasikan kualitas, superioritas, rasa aman, pencitraan, kepribadian, atau kata-kata dengan arti yang sama. Pembatasan non-harga ini juga dapat secara kasat mata dilihat dari larangan merokok di kawasan publik tertentu seperti rumah sakit dan puskesmas, stasiun kereta api dan dalam seluruh gerbong serta kawasan peribadatan. Tidak ketinggalan, inisiasi privat berupa penempelan slogan kawasan bebas rokok sudah semakin banyak ditemukan baik di rumah makan, tempat hiburan dan arena bermain. Singkatnya, pembatasan edar produk rokok baik dari aspek harga maupun dari aspek lainnya semakin gencar dilaksanakan.

Sikap pemerintah terhadap produk ini terlihat sangat gamang. Pada satu sisi, pemerintah memiliki tanggung jawab untuk melindungi masyarakat dari efek negatif atau rokok bagi kesehatan. Namun, pada sisi lain pemerintah sangat membutuhkan rokok sebagai sumber utama pendulang cukai. Akibatnya, setiap ada keingingan untuk menaikkan cukai rokok untuk menahan laju konsumsi, pemerintah terkesan ragu-ragu karena sangat takut kehilangan sumber potensial penerimaan cukai dalam jumlah cukup besar. Kenaikan cukai rokok relatif pelan sehingga selalu lebih lambat dibandingkan dengan kenaikan riil pendapatan rumah tangga perokok. Ketakutan ini mungkin cukup beralasan mengingat sejumlah studi menunjukkan bahwa elastisitas permintaan rokok di sejumlah negara berkembang relatif lebih besar. Jika di negara maju elastisitas permintaan rokok mencapai sekitar -0,2 hingga $-0,5$ maka sebaliknya di negara berkembang bisa mencapai -0,5 hingga -1 (Chaloupka, Hu, Warner, Jakob, \& Yurekli, 2000). Hasil ini telah dikonfirmasi oleh Hidayat dan Tabrany (2010) dengan menggunakan data rumah tangga di Indonesia. Studi empiris tersebut menemukan bahwa elastisitas permintaan rokok berkisar antara $-0,28$ (jangka pendek) hingga -0,73 (jangka panjang). Merujuk pada hasil riset ini, tentu dapat dimaklumi mengapa pemerintah terkesan ragu-ragu untuk menaikkan cukai rokok secara signifikan.

Sejumlah kajian empiris sejauh ini sebagian besar menyimpulkan bahwa elastisitas permintaan rokok di negara maju dengan tingkat pendapatan yang relatif tinggi, ternyata relatif inelastik. Sebaliknya, di negara berkembang, termasuk Indonesia, cenderung relatif elastis. Studi empiris mengenai perilaku konsumsi rokok sejauh ini belum membahas isu tentang variabilitas elastisitas permintaan terkait dengan berbagai tipe rokok yang beredar. Estimasi elastisitas sejauh ini mengasumsikan bahwa elastisitas bersifat seragam tanpa mempertimbangkan jenis rokok. Pertanyaan mengenai kemungkinan adanya elastisitas yang berbeda-beda (asimetri) ini menjadi sangat relevan untuk kasus Indonesia karena jenis rokok yang tersedia di pasaran sangat bervariasi mulai dari merek, kemasan hingga proses pembuatan. Tak pelak, jenis cukai yang diberlakukan juga tidak tunggal namun bermacam-macam tergantung dari jenis rokok yang ada. Untuk mengisi gap kajian 
empiris inilah maka paper ini secara khusus akan mengupas respon asimetri elastisitas permintaan rokok untuk mendapat estimasi elastisitas yang lebih presisi. Selanjutnya hasiln estimasi tersebut dapat diterapkan untuk melakukan simulasi perubahan penerimaan pajak jika pemerintah bermaksud menaikkan cukai rokok.

Kajian yang komprehensif tentang perilaku merokok sudah banyak dilakukan baik di dalam negeri maupun di dalam negeri. Beberapa kajian bahkan ada yang dipublikasikan secara rutin dalam beberapa periodik. Salah satunya adalah kajian ekonomi tembakau di Australia yang dilakukan secara komprehensif sejak tahun 1989 (Scollo \& Winstanley, 2012). Studi yang dilakukan sangat lengkap mulai dari konsumsi rokok, efek kesehatan rokok, penerapan cukai, periklanan hingga kontrol terhadap konsumsi rokok. Riset rokok dengan topik khusus mengenai perilaku merokok di kalangan remaja dilakukan di China (Zhao, Konishi, \& Glewwe, 2010). Penelitian ini secara meyakinkan menemukan adanya parental effect dalam perilaku merokok remaja. Kebiasaan merokok remaja sebagian besar diwariskan oleh kebiasaan merokok orang tuanya. Tentu saja temuan ini tidak terlalu mengejutkan. Hasil lain yang menarik adalah dengan mengontrol variabel lama sekolah, ditemukan kaitan antara kebiasaan merokok dengan hasil test matematika. Merokok satu batang per hari saat usia dini menyebabkan penurunan skor matematika sebesar 0,1 standar deviasi. Namun, peneliti tidak menemukan bukti signifikan antara kebiasaan merokok ini dengan test bahasa dan lama sekolah (years of schooling).

Karakteristik konsumsi rokok yang bersifat khas, telah menjadi kajian khusus dari para ahli. Sebagaimana komoditi lain pada umumnya, keputusan konsumen untuk merokok ditentukan oleh pertimbangan biaya (cost) dan keuntungan (benefit). Prinsip dasar yang berlaku juga sama, yakni konsumen akan merokok jika kenikmatan dari merokok melampaui biaya yang akan ditimbulkan, termasuk biaya kesehatan dari merokok. Konsumenjuga diasumsikan sadar bahwa merokok akan membawa konsekwensi kecanduan. Mengingat sifatnya yang khas, konsumsi rokok termasuk salah satu aktivitas yang harus diatur oleh negara. Salah satu bentuk regulasi pemerintah adalah pengenaan pajak atau cukai untuk setiap pembelian rokok. Justifikasi pengenaan cukai untuk konsumsi rokok adalah adanya potensi eksternalitas yang cukup tinggi dari aktivitas tersebut. Salah satu contoh, merokok memiliki pengaruh negatif terhadap perokok pasif dalam bentuk tingginya biaya kesehatan (the health costs of secondhand smoke). Contoh lain, merokok dapat memiliki implikasi yang tidak ringan terhadap kesehatan janin baik dalam jangka pendek maupun jangka panjang. Eksternalitas dalam bentuk implikasi kesehatan terhadap perokok pasif dan janin masih diperdebatkan karena tipe eksternalitas tersebut seharusnya sudah dipertimbangkan dalam keputusan individu dalam merokok. Dengan kata lain, implikasi eksternalitas yang muncul mungkin tidak sebesar yang diperkirakan.

Pendekatan lama dalam memandang perilaku merokok mungkin tidak cukup dijadikan pijakan justifikasi regulasi rokok. Gruber (2003) menjelaskan beberapa point penting. Pertama, asumsi bahwa konsumen memiliki informasi yang lengkap (fully informed) patut diragukan. Sebagaimana dimaklumi bahwa inisiasi merokok dimulai sejak masa remaja. Anak muda sebagai perokok pemula mungkin telah memperoleh informasi yang cukup banyak tentang bahaya merokok. Namun sebagian besar masih kurang menyadari akan konsekwensi dari "kecanduan" akibat merokok. Sebuah survei menunjukkan bahwa diantara 56 persen remaja yang mengatakan tidak akan merokok pada lima tahun mendatang, hanya 31 persen remaja yang betul-betul berhenti merokok pada lima tahun setelah survei pertama. Sebaliknya, sebanyak 72 persen remaja yang sebelumnya menyatakan akan menjadi perokok, kenyatannya justru 74 persen yang menjadi perokok aktif. Kedua, perokok aktif dalam prakteknya sulit untuk betul-betul berhenti merokok meskipun sebenarnya mereka sangat menginginkan untuk menghentikan kebiasaan tersebut.

Gruber (2003) secara lebih jauh menawarkan arternatif model konsumsi rokok dengan menambahkan fitur time-inconsistent dalam utilitas konsumen. Sejumlah studi menunjukkan bahwa sangat mudah bagi perokok untuk mengatakan bahwa tidak mengapa mereka merokok "hari ini" dengan janji akan berhenti pada "esok hari". Namun "esok hari" tidak pernah datang. Setelah hari esok tiba menjadi hari ini, perokok kembali pada kebiasaan lama. Kasus ini mungkin sama dengan janji diet yang selalu gagal direalisasikan. Intinya, diperlukan self-control bagi perokok untuk benar-benar mengendalikan 
kebiasaan merokok. Dari sinilah kemudian argumentasi cukai sebagai regulasi harga menemukan landasan pijakan teoritisnya. Melalui aturan cukai rokok, aktivitas merokok dalam pandangan konsumen adalah sesuatu yang sifatnya costly. Instrumen cukai memang bukan sarana (devices) terbaik karena penggunaannya bisa memicu adanya penyelundupan rokok, pemalsuan cukai dan lain sebagainya. Sungguhpun demikian, pengendalian ini tetap diperlukan.

Baik pendekatan lama maupun pendekatan baru mengenai konsumsi rokok sama-sama mendukung diperlukannya peran pemerintah dalam mengatur harga rokok. Akan tetapi, argumentasi yang dimunculkan bisa berbeda. Pendekatan lama lebih mengedepankan faktor eksternalitas dari merokok, sementara pendekatan baru lebih menitikberatkan pentingnya instrumen cukai sebagai alat kontrol bagi perokok supaya lebih dapat "mengendalikan" kebiasaan merokok. Bagi kelompok rumah tangga miskin, elastisitas harga dari rokok cenderung lebih tinggi dibandingkan dengan rumah tangga kaya. Artinya, peningkatan harga betul-betul akan mengurangi konsumsi rokok secara signifikan bagi rumah tangga miskin. Demikian halnya, elastisitas harga rokok relatif lebih tinggi bagi perokok remaja dibandingkan dengan kelompok dewasa. Jika ditilik dari perspektif lama, pengenaan cukai akan menyebabkan perokok menjadi worse-off. Sebaliknya dari persepektif baru (cukai sebagai pengendali), pengenaan cukai justru berimplikasi positif terhadap perokok. Untuk diskusi lebih lanjut, dapat ditelusuri dalam artikel Grubel dan Mullainathan (2002).

Para ahli juga secara khusus menelaah fungsi cukai sebagai pengendali konsumsi untuk sin commodity ( $\mathrm{O}^{\prime}$ Donoghue \& Rabin, 2006; Lockwood \& Taubinsky, 2015). Secara konsisten hasil riset menunjukkan bahwa piranti cukai masih menjadi alat yang paling efektif untuk menahan laju konsumsi rokok (dan juga sin commodity lainnya). Sungguhpun demikian, peran penegakan hukum juga akan sangat membantu efektivitas kebijakan pembatasan konsumsi rokok. Dengan menggunakan pendekatan eksperimentasi laboratorium, peneliti MD FEB UGM menemukan bukti empiris bahwa penindakan yang tepat akan mengurangi secara optimal kasus kecurangan dalam penerapan pita cukai termasuk adanya pemalsuan dan penghindaran cukai (MD FEB
UGM, 2016). Riset ini merupakan tindak lanjut dari kajian tentang implikasi kebijakan bebas cukai di kawasan khusus (MD FEB UGM, 2015). Tanpa ada pengawasan yang memadahi, kebijakan cukai yang ditujukan untuk mengendalikan konsumsi tidak cukup efektif.

Selain menggunakan pendekatan parsial, studi empiris mengenai komoditi rokok juga dilakukan dengan topik beragam dengan metodologi yang kompleks. Ekpu dan Brown (2015) menggunakan pendekatan analisis meta untuk menguji perilaku merokok di beberapa negara maju selama periode 1992 hingga tahun 2014 dengan merangkum beberapa jurnal ilmiah, laporan medis dan jurnal kesehatan. Hasil kajian menunjukkan bahwa sekitar 15 persen pengeluaran aggregat di bidang kesehatan negara-negara maju disebakan oleh kebiasaan merokok. Sungguhpun demikian, tidak dapat dipungkiri bahwa disamping biaya yang muncul, industri rokok cukup banyak memberi keuntungan ekonomi. Manfaat ekonomi tersebut tidak hanya dalam bentuk penerimaan dari pajak namun juga dalam bentuk penyerapan tenaga kerja. Kompleksitas masalah rokok yang dibahas oleh para ahli seolah dapat membentuk cabang baru dalam disiplin ilmu ekonomi, yakni ekonomika tembakau (Marti, 2011). Kajiannya tidak hanya terbatas pada analisis biaya manfaat rokok secara ekonomi, namun juga rokok dalam perspektif kesehatan, lingkungan dan juga aspek lainnya yang terkait.

Organisasi paper ini tersusun sebagai berikut. Bagian pendahuluan berisi tentang latar belakang penulisan dan dilanjutkan dengan telaah teoritis serta riset terdahulu. Selanjutnya seksi metodologi memuat model analisis permintaan rokok dengan pendekatan myopic. Dalam bagian ini pula dibahas isu-isu terkait dengan estimasi utama serta variasi teknik analisis untuk menjamin hasil yang robust. Setelah itu dalam bagian analisis dan pembahasan akan disampaikan hasil estimasi serta simulasi efek kenaikan cukai terhadap penerimaan negara. Paper ini akan ditutup dengan seksi kesimpulan dan saran kebijakan.

\section{DATA DAN METODOLOGI}

Para ahli telah mengusulkan beberapa model estimasi konsumsi rokok dari model standar, model rasional adiktif dan model miopik adiktif (Hidayat \& Thabrany, 2010). Berdasarkan studi Hidayat dan Thabrany (2010), model miopik 
ternyata lebih sesuai dengan kasus di Indonesia. Konstruksi model tersebut adalah:

$$
C_{i t}=\alpha+\beta_{1} C_{i t-1}+\beta_{2} P c_{i t}+\beta_{3} x_{i t}^{\prime}+v_{i}+\varepsilon_{i t}
$$

Fitur miopik dari model diatas akan ditentukan oleh koefisien $\beta$ _ 1 yang melekat dengan variabel konsumsi pada periode sebelumnya $\left(C_{i t-1}\right)$. Sementara itu, koefisien utama model diatas adalah $\beta_{2}$ yang secara teknis menggambarkan marjinal konsumsi akibat perubahan harga. Dalam studi empiris, koefisien ini menunjukkan elastisitas harga jika variabel harga dan konsumsi yang digunakan dihitung dalam bentuk logaritma. Variabel kontrol yang digunakan terdiri dari karakteristik responden seperti usia, jenis kelamin, status dalam rumah tangga serta status perkawinan. Semua variabel kontrol ini diwakili oleh vektor $x^{\prime}$ dalam model (1) diatas. Selain faktor terobservasi, model diatas juga mengakomodasi unobserved factor yang memiliki peran penting terhadap keputusan konsumsi, seperti preferensi konsumen.

Model estimasi diatas dalam paper ini akan dimodifikasi dengan mempertimbangkan beberapa faktor. Pertama, karakteristik kecanduan (adiktif) dari merokok tidak hanya dapat dilihat dari konsumsi rokok periode sebelumnya (apalagi periode sebelumnya ternyata relatif sangat jauh). Beberapa alternatif variabel dapat digunakan seperti kebiasaan merokok per bungkus/hari dan intensitas merokok dalam periode tertentu. Kajian Grubel (2003) secara jelas menyiratkan aspek kebisaan merokok ini dengan rinci. Kedua, kebiasaan merokok sangat besar kemungkinan diakibatkan oleh faktor keluarga atau rumah tangga. Dalam istilah Zao et.al (2010) masalah ini disebut sebagai parental effect. Mengingat adanya pertimbangan tersebut, maka model (1) dimodifikasi dengan memasukkan variabel lain yang relevan serta unit analisis berjenjang: level individu dan rumah tangga.

$C_{i h}=\alpha+\beta_{1} \bar{C}_{i h}+\beta_{2} P c_{i h}+\beta_{3} x_{i h}^{\prime}+v_{i}+d_{h}+\varepsilon_{i h}$

Konstruksi model (2) diatas sesuai dengan data dengan tipe silang tempat (cross-section). Sifat adiktif diwakili oleh variabel $\bar{C}_{i h}$ yang menunjukkan rata-rata kebiasaan merokok. Untuk mengakomodasi parental effect, model diatas menambahkan unsur $d_{h}$ yang bernilai sama untuk responden dengan unit rumah tangga yang sama, namun bervariasi jika responden berasal dari rumah tangga yang berbeda.

Aplikasi Ordinary Least Square (OLS) untuk mengestimasi model (1) atau model (2) berpotensi menghasilkan estimator yang bias. Pertama, variabel kebiasaan merokok yang digunakan sebagai proksi untuk mengindikasikan adanya sifat miopik adiktif bersifat endogen. Masalah endogenitas ini juga telah didiskusikan secara panjang lebar oleh Hidayat dan Thabbrany (2010). Kedua, terdapat faktor unobserved dalam level rumah tangga yang layak dicurigai mempengaruhi elastisitas permintaan rokok. Individu dalam lingkungan rumah tangga yang relatif permisif terhadap rokok, relatif memiliki gaya kebisaan merokok yang lebih lama. Untuk mengatasi masalah endogenitas yang berpotensi bias, penelitian ini menggnakan pendekatan instrumental variables melalui regresi dua tahap (2SLS). Kandidat variabel intrumen yang digunakan dalam penelitian ini adalah besarnya tarif cukai. Sebagai instrumen kebijakan, variabel besarnya cukai secara konseptual adalah eksogen. Selain itu, besarnya cukai tentu berhubungan dengan kebiasaan merokok. Ditilik dari syarat penggunaan variabel instrumen, instrumen cukai secara teori telah memenuhi syarat eksogenitas dan syarat relevansi. Penjelasan yang lebih dalam mengenai syarat eksogenitas dan relevansi ini dapat dilihat dalam Wooldridge (2009).

Penggunaan instrumental variables untuk mengestimasi model (2) secara teori memang dapat memperbaiki problem endogenitas di levelindividu. Akan tetapi, sebagaimana telah disinggung, masalah tidak hanya datang dari level individu. Dalam level rumah tangga ditenggarai terdapat efek yang berpotensi mempengaruhi hubungan merokok dengan variabel penjelas utama. Untuk mengisolasi pengaruh dalam level rumah tangga, penelitian ini menggunakan pendekatan fixed effect level rumah tangga. Pendekatan ini dilakukan dengan menyusun kembali semua variabel dalam bentuk deviasi terhadap rata-ratanya.

$\ddot{C}_{i h}=\beta_{1} \bar{C}_{i h}+\beta_{2} \ddot{P}_{i h}+\beta_{3} \ddot{x}_{i h}^{\prime}+\ddot{\varepsilon}_{i h}$

Relevansi penggunaan berbagai metode estimasi yang digunakan dalam paper ini akan terkonfirmasi melalui hasil uji empiris. Secara teori, pengabaian terhadap masalah endogeneity dalam kasus konsumsi rokok ini berpotensi mengakibatkan hasil estimasi yang undervalue. Sebagai akibatnya, kesimpulan penelitian yang diperoleh mengenai perilaku merokok bisa jadi tidak konsisten.

Data yang digunakan dalam penelitian ini adalah hasil Survei Aspek Kehidupan Rumah 
Tabel 1. Rangkuman Statistik Variabel Utama

\begin{tabular}{llll}
\hline \multicolumn{1}{c}{ Variabel } & \multicolumn{1}{c}{ Deskriptif } & Mean & St.dev \\
\hline lnbks & Konsumsi rokok (dalam logaritma) & 0,118 & 0,455 \\
lnprice & Harga rokok (dalam logaritma) & 9,284 & 0,448 \\
lncukai & Tarif cukai (dalam logaritma) & 5,841 & 0,141 \\
age first & Usia pertama merokok (tahun) & 19,64 & 7,13 \\
day bks & Rata-rata konsumsi per hari & 1,019 & 0,713 \\
female & Perempuan (1); Laki-laki (0) & 0,523 & 0,499 \\
head & Kepala rumah tangga (1); lainnya (0) & 0,377 & 0,484 \\
age & Usia responden (tahun) & 38,43 & 17,65 \\
married & Menikah (1); lainnya (0) & 0,669 & 0,470 \\
\hline \hline Sumber: Keculi data tentang cukai semua dotadisarikndrifls-5(2014).
\end{tabular}

Sumber: Kecuali data tentang cukai, semua data disarikan dari IFLS-5 (2014).

Tangga Indonesia (SAKERTI) atau lebih dikenal sebagai Indonesia Family Life Survey (IFLS). IFLS merupakan survei data panel rumah tangga yang dimulai sejak tahun 1993 (IFLS-1). Basis sampel yang digunakan adalah rumah tangga pada tahun 1993 yang di interview kembali pada gelombang survei selanjutnya. Sampling dilakukan dengan strategi stratifikasi pada level provinsi dilanjutkan dengan stratifikasi pada level kota atau desa. Dengan alasan efisiensi dan efektivitas, maka hanya 13 provinsi di Indonesia yang terpilih sebagai sampel. Sampel terdiri dari 4 provinsi di Sumatera (Sumatera Utara, Sumatera Barat, Sumatera Selatan dan Lampung), 5 provinsi di Jawa (DKI, Jawa Barat, Jawa Tengah, Yogyakarta dan Jawa Timur). Representasi sampel adalah 83 persen populasi Indonesia.

Pada masing-masing provinsi tersebut, dipilih secara acak sejumlah Enumeration Area (EA) menggunakan sample frame SUSENAS 1993. Rumah tangga sampel dalam SUSENAS 1993 mencakup sekitar 60.000 rumah tangga. Dengan metode ini terpilih 321 EA dari 13 provinsi terpilih. Untuk masing-masing EA dipilih secara acak rumah tangga sampel yang menghasilkan rumah tangga sebanyak 7.730 rumah tangga sebagai sampel. Selanjutnya dari rumah tangga terpilih, hanya 7.224 rumah tangga yang kemudian benar-benar berhasil diwawancara. Sampel rumah tangga ini diikuti hingga gelombang survei berikutnya dan mengembang karena adanya rumah tangga baru yang memisahkan diri dari rumah tangga awal (split household) sehingga pada survei
2007 (IFLS-4) sudah terkumpul sebanyak 13.995 rumah tangga sampel. Untuk kasus kebiasaan merokok, IFLS menyediakan hasil survei dalam Buku 3B Seksi Kebiasaan Merokok. Saat ini, IFLS telah dirilis untuk survei gelombang ke lima pada tahun 2014. Responden yang diwawancarai adalah anggota rumah tangga usia 15 tahun ke atas. Pada IFLS-5 (2014) terdapat sekitar 34.000 responden usia dewasa, namun yang berhasil diwawancarai secara konsisten dalam seksi kebiasaan merokok adalah sekitar 6.000 responden.

Tabel 1 menyajikan rangkuman statistik variabel utama dalam penelitian ini. Data penelitian diambil dari Seksi Kebisaan Merokok (KM) dalam Buku 3B IFLS wave ke 5 yang rilis pada tahun 2014. Data mengenai cukai rokok tidak tersedia dalam survei IFLS namun diperoleh dari rilis Bea dan Cukai RI.

\section{HASIL DAN PEMBAHASAN}

Estimasi model konsumsi rokok dimulai dengan versi yang paling sederhana hingga menambah beberapa variabel kontrol yang relevan. Model sedernana menggunakan variabel utama dalam satuan level, sementara model pengembangan menggunakan satuan pengukuran logaritma untuk memperoleh estimator elastisitas permintaan. Hasil estimasi model dasar dapat diperhatikan dalam Tabel 2 sebagai berikut.

Kolom (1) dalam Tabel 2 menyajikan estimasi dasar model permintaan rokok memggunakan variabel jumlah permintaan dan tingkat harga masing-masing diukur dalam satuan 
Tabel 2. Estimasi Model Utama

\begin{tabular}{|c|c|c|c|}
\hline VARIABLES & $\begin{array}{c}\text { (1) } \\
\text { bungkus }\end{array}$ & $\begin{array}{c}(2) \\
\operatorname{lnbks}\end{array}$ & $\begin{array}{c}(3) \\
\operatorname{lnbks}\end{array}$ \\
\hline Inprice & - & $\begin{array}{c}-0.460^{\star * * *} \\
(0.0272)\end{array}$ & $\begin{array}{c}-0.470^{\star \kappa * k} \\
(0.0283)\end{array}$ \\
\hline agefirst & $\begin{array}{l}-0.000659 \\
(0.00444)\end{array}$ & $\begin{array}{l}-0.000894 \\
(0.000887)\end{array}$ & $\begin{array}{l}-0.000504 \\
(0.000935)\end{array}$ \\
\hline day bks & $\begin{array}{l}0.229^{* \star * k} \\
(0.0426)\end{array}$ & $\begin{array}{l}0.106^{* * * *} \\
(0.00951)\end{array}$ & $\begin{array}{c}0.108^{* * *} \\
(0.00958)\end{array}$ \\
\hline intens & $\begin{array}{l}0.0587^{* *} \\
(0.0253)\end{array}$ & $\begin{array}{c}0.00282 \\
(0.00514)\end{array}$ & $\begin{array}{c}0.00325 \\
(0.00514)\end{array}$ \\
\hline age & - & - & $\begin{array}{l}-0.00135^{* x} \\
(0.000538)\end{array}$ \\
\hline female & - & - & $\begin{array}{l}0.112^{* * *} \\
(0.0418)\end{array}$ \\
\hline head & - & - & $\begin{array}{l}0.0269^{* *} \\
(0.0134)\end{array}$ \\
\hline married & - & - & $\begin{array}{c}-0.0321^{* *} \\
(0.0144)\end{array}$ \\
\hline price & $\begin{array}{c}-9.79 \mathrm{e}-05^{\star \star \star} \\
(1.81 \mathrm{e}-05)\end{array}$ & - & \\
\hline Constant & $\begin{array}{c}2.177^{* \kappa * k} \\
(0.260)\end{array}$ & 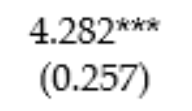 & $\begin{array}{c}4.420^{\star \star \star} \\
(0.272)\end{array}$ \\
\hline Observations & 7,111 & 7,104 & 7,102 \\
\hline R-squared & 0.056 & 0.221 & 0.224 \\
\hline
\end{tabular}

level. Sesuai dugaan teori, tingkat harga memiliki pengaruh negatif terhadap permintaan. Beberapa variabel penjelas disertakan dalam model dasar ini seperti usia merokok pertama kali (agefirst), jumlah rata-rata merokok biasanya (day_bks) dan intensitas merokok (intents). Kecuali faktor usia awal merokok, semua variabel penjelas relatif signifikan dalam level konvensional (lima persen atau satu persen).

Estimasi model dasar memiliki keunggulan interpretasi yang lebih langsung. Namun demikian, hampir sebagian riset permintaan bertujuan untuk menemukan koefisien elastisitas permintaan. Koefisien elastisitas permintaan dapat diperoleh melalui model double log, yakni mengukur variabel utama (variable of interest) dengan satuan logaritma. Diskusi lebih rinci mengenai hal ini dapat ditelusuri lebih jauh dalam Gujarati (2003). Kolom (2) dalam Tabel 2 menyajikan hasil estimasi permintaan rokok dengan variabel konsumsi dan harga yang masing-masing telah dinyatakan dalam bentuk logaritma. Hasil estimasi penting dapat diperhatikan dalam baris pertama yang menunjukkan besarnya elastisitas permintaan.

Kolom (2) Tabel 2 pada dasarnya mereplikasi model estimasi dalam kolom (1) dengan modifikasi pengukuran konsumsi dan harga. Sebelum melakukan interpretasi terhadap hasil estimasi tersebut, terlebih dahulu dapat dilihat performa model dalam kolom (2) dengan kolom (1). Koefisien populer yang sering digunakan dalam analisis ekonometrika adalah $R$-squared. Model dasar dalam kolom (1) menunjukkan hasil $R$-squared sebesar 5,6 persen, sementara untuk kolom (2) adalah sebesar 22,1 persen. Secara jelas, performa model dalam kolom (2) ditinjau dari kualifikasi goodness of fit, relatif lebih unggul. Untuk itulah maka dalam analisis selanjutnya, model logaritma ini akan digunakan sebagai acuan dasar bagi pengembangan model berikutnya. Nilai -0,46 dapat diinterpretasikan bahwa jika terdapat keinaikan harga rokok sebesar 1 persen, maka 
Tabel 3. Estimasi Model OLS, 2SLS dan FIXED

\begin{tabular}{|c|c|c|c|}
\hline VARIABLES & $\begin{array}{l}\text { (1) } \\
\text { OLS }\end{array}$ & $\begin{array}{c}(2) \\
\text { 2SLS }\end{array}$ & $\begin{array}{c}(3) \\
\text { FIXED }\end{array}$ \\
\hline Inprice & $\begin{array}{l}-0.470^{\star \star \star \kappa} \\
(0.0283)\end{array}$ & $\begin{array}{l}-0.582^{\star \star *} \\
(0.0792)\end{array}$ & $\begin{array}{l}-0.786^{*} \\
(0.442)\end{array}$ \\
\hline agefirst & $\begin{array}{l}-0.000504 \\
(0.000935)\end{array}$ & $\begin{array}{l}0.00783^{*} \\
(0.00457)\end{array}$ & $\begin{array}{l}0.00235 \\
(0.0111)\end{array}$ \\
\hline day bks & $\begin{array}{l}0.108^{\star \star \star} \\
(0.00958)\end{array}$ & $\begin{array}{l}1.017^{* \star *} \\
(0.490)\end{array}$ & $\begin{array}{c}1.718 \\
(3.583)\end{array}$ \\
\hline intens & $\begin{array}{c}0.00325 \\
(0.00514)\end{array}$ & $\begin{array}{l}-0.145^{*} \\
(0.0820)\end{array}$ & $\begin{array}{l}-0.257 \\
(0.568)\end{array}$ \\
\hline age & $\begin{array}{l}-0.00135^{\star \star} \\
(0.000538)\end{array}$ & $\begin{array}{l}0.000120 \\
(0.00123)\end{array}$ & $\begin{array}{l}-0.00179 \\
(0.00400)\end{array}$ \\
\hline female & $\begin{array}{l}0.112^{* \kappa *} \\
(0.0418)\end{array}$ & $\begin{array}{l}0.295^{\star \star \star} \\
(0.113)\end{array}$ & $\begin{array}{c}0.562 \\
(1.209)\end{array}$ \\
\hline head & $\begin{array}{l}0.0269^{\text {*** }} \\
(0.0134)\end{array}$ & $\begin{array}{l}-0.0608 \\
(0.0522)\end{array}$ & $\begin{array}{l}-0.135 \\
(0.298)\end{array}$ \\
\hline married & $\begin{array}{l}-0.0321^{\text {*k }} \\
(0.0144)\end{array}$ & $\begin{array}{l}-0.0971^{* \star} \\
(0.0471)\end{array}$ & $\begin{array}{l}-0.203 \\
(0.424)\end{array}$ \\
\hline Constant & $\begin{array}{l}4.420^{\star * * *} \\
(0.272)\end{array}$ & $\begin{array}{c}4.662^{* \ldots *} \\
(0.436)\end{array}$ & $\begin{array}{c}6.327^{* * *} \\
(1.815)\end{array}$ \\
\hline $\begin{array}{l}\text { Observations } \\
\text { R-squared }\end{array}$ & $\begin{array}{l}7,102 \\
0.224\end{array}$ & 6,583 & 6,583 \\
\hline Number of $\mathrm{HH}$ & & & 5,893 \\
\hline
\end{tabular}

permintaan rokok akan turun sebesar -0,46 persen. Hasil ini menyiratkan bahwa efek kenaikan harga rokok terhadap konsumsi rokok relatif inelastis. Jika dikomparasikan dengan riset Chaloupka et.al (2000) hasil ini terlihat bertentangan. Riset mengenai elastisitas permintaan rokok secara umum banyak menemukan bahwa elastisitas permintaan rokok di negara berkembang relatif lebih sensitif terhadap perubahan harga (dengan elastisitas permintaan diatas 0,5 hingga 1 ).

Hasil estimasi elastisitas permintaan rokok sebagaimana disajikan dalam kolom (2) Tabel 2 tentu bukanlah hasil final. Hasil tersebut diperoleh tanpa mengontrol lebih dalam terhadap adanya pengaruh faktor lain yang relevan. Faktor lain yang relevan dapat berasal dari aspek yang dapat diobservasi dan aspek atau faktor yang tidak terobservasi. Faktor-faktor terobservasi dapat langsung disertakan dalam model. Sebagaimana telah dibahas dalam bagian model analisis, faktor penting yang menjadi penentu konsumsi rokok adalah karakteristik responden. Tabel 2 dalam kolom (3) memperlihatkan adanya tambahan variabel bebas antara lain usia responden (age); jenis kelamin (female); status dalam rumah tangga (head) dan status pernikahan (married). Kehadiran variabel tambahan dalam model ini secara umum menyumbang beberapa perubahan terhadap performa model. Pertama, meskipun relatif kecil, terjadi penambahan dalam koefisien $R$-square. Kedua, ini yang lebih penting, terjadi perubahan dalam koefisien elastisitas permintaan rokok dari -0,46 menjadi $-0,47$. Betapapun relatif kecilnya tambahan magnitute dari koefisien elastistitas pasca tambahan variabel, hasil ini tetap menyiratkan bahwa dengan penambahan variabel kontrol yang relevan, efek bersih dari koefisien penjelas terhadap variabel terikat menjadi lebih presisi.

Selain memperbaiki performa estimasi model, penambahan variabel baru menghasilkan beberapa temuan yang cukup menarik. Pertama, faktor umur ternyata berpengaruh negatif terhadap konsumsi rokok. Semakin tua usia responden maka 
Tabel 4. Estimasi Model Permintan Rokok Asimetri

\begin{tabular}{|c|c|c|c|}
\hline VARIABLES & $\begin{array}{c}(1) \\
\text { lnbks }\end{array}$ & $\begin{array}{c}(2) \\
\text { lnbks }\end{array}$ & $\begin{array}{c}(3) \\
\text { lnbks }\end{array}$ \\
\hline lnprice & $\begin{array}{c}-0.470^{\star \star \star *} \\
(0.0283)\end{array}$ & $\begin{array}{c}-0.498^{* \times * *} \\
(0.0321)\end{array}$ & $\begin{array}{c}-0.508^{* k * *} \\
(0.0328)\end{array}$ \\
\hline _Itype_2 & - & $\begin{array}{l}0.115^{* \times *} \\
(0.0183)\end{array}$ & - \\
\hline _Itype_3 & - & $\begin{array}{l}0.131^{* * *} \\
(0.0202)\end{array}$ & - \\
\hline agefirst & $\begin{array}{c}-0.000504 \\
(0.000935)\end{array}$ & $\begin{array}{c}-0.000634 \\
(0.000953)\end{array}$ & $\begin{array}{c}-0.000629 \\
(0.000953)\end{array}$ \\
\hline dax bles & $\begin{array}{c}0.108^{* \times *} \\
(0.00958)\end{array}$ & $\begin{array}{c}0.104^{* * *} \\
(0.00991)\end{array}$ & $\begin{array}{c}0.104^{* * * *} \\
(0.00992)\end{array}$ \\
\hline intens & $\begin{array}{c}0.00325 \\
(0.00514)\end{array}$ & $\begin{array}{c}0.00844 \\
(0.00534)\end{array}$ & $\begin{array}{c}0.00843 \\
(0.00534)\end{array}$ \\
\hline age & $\begin{array}{l}-0.00135^{* *} \\
(0.000538)\end{array}$ & $\begin{array}{c}-0.000551 \\
(0.000552)\end{array}$ & $\begin{array}{c}-0.000553 \\
(0.000553)\end{array}$ \\
\hline female. & $\begin{array}{l}0.112^{* \ldots *} \\
(0.0418)\end{array}$ & $\begin{array}{c}0.103^{\star \star} \\
(0.0431)\end{array}$ & $\begin{array}{c}0.103^{* *} \\
(0.0431)\end{array}$ \\
\hline head & $\begin{array}{l}0.0269^{* *} \\
(0.0134)\end{array}$ & $\begin{array}{c}0.0255^{\star} \\
(0.0142)\end{array}$ & $\begin{array}{c}0.0253^{*} \\
(0.0142)\end{array}$ \\
\hline married & $\begin{array}{c}-0.0321^{* *} \\
(0.0144)\end{array}$ & $\begin{array}{c}-0.0240 \\
(0.0148)\end{array}$ & $\begin{array}{c}-0.0239 \\
(0.0148)\end{array}$ \\
\hline pr_type2 & - & - & $\begin{array}{l}0.0126^{* * *} \\
(0.00193)\end{array}$ \\
\hline pr_types & - & - & $\begin{array}{l}0.0141^{* \times *} \\
(0.00213)\end{array}$ \\
\hline Constant & $\begin{array}{l}4.420^{* \times * \pi} \\
(0.272)\end{array}$ & $\begin{array}{c}4.553^{\text {*x< }} \\
(0.297)\end{array}$ & $\begin{array}{c}4.636^{\mathrm{x} \times \mathrm{x}} \\
(0.303)\end{array}$ \\
\hline Observations. & 7,102 & 6,583 & 6,583 \\
\hline R-squared & 0.224 & 0.229 & 0.229 \\
\hline
\end{tabular}

semakin jarang konsumsi rokok yang lakukan. Temuan ini tentu cukup relevan jika dikaitkan dengan fakta bahwa efek rokok terhadap konsumen biasanya terjadi dalam jangka panjang. Begitu gejala kesehatan muncul, maka nasehat dokter manapun terhadap perokok akan sama: hentikan merokok atau, jika belum bisa, kurangilah! Kedua, faktor jenis kelamin juga mempengaruhi kebiasaan merokok. Hasil investigasi empiris menunjukkan bahwa perokok perempuan lebih banyak merokok dibandingkan dengan perokok laki-laki. Temuan ini menarik karena hampir semua studi laporan tentang prevalensi merokok, perokok perempuan relatif lebih sedikit. Investigasi terhadap kasus ini tentu sangat menarik namun berada di luar pokok bahasan paper ini. Ketiga, merokok lebih banyak dilakukan oleh kepala rumah tangga dibandingkan dengan anggota rumah tangga yang lain. Dalam kultur budaya Indonesia, kepala rumah tangga memang relatif lebih mudah menjadi perokok aktif dibandingkan yang lain karena fungsi kontrol terhadap rumah tangga biasanya dipegang oleh kepala rumah tangga. Keempat, ini juga menarik untuk diperhatikan, merokok lebih sedikit dilakukan oleh responden yang sudah menikah. Temuan ini bisa jadi diterima oleh karena kebiasaan merokok kerap "diminta" untuk dikurangi setelah menikah jika pasangan hidup tidak merasa nyaman dengan asap rokok. Apapun itu bentuknya, penambahan variabel karakteristik responden sedikit banyak mempengaruhi performa model.

Memasukkan semua variabel kontrol yang relevan dalam model harus dilakukan untuk menghindari bias akibat pengabaian variabel penting (ommited variables). Dalam banyak kasus, variabel penting tersebut justru bersifat tak dapat diobservasi secara langsung. Variabel un-observed ini dalam model estimasi (2) diwakli oleh unsur $v_{i}$ dan $d_{h}$. Masing-masing subsrcipt $i$ dan $h$ menunjukkan asal faktor un-observed tersebut, masing-masing dalam level individu atau rumah tangga.

Untuk melihat dampak kontrol terhadap faktor un-observed, penelitian ini melakukan 
estimasi ulang dengan beberapa pendekatan yang berbeda. Pertama, melakukan teknik 2SLS untuk mengontrol endogeneity dalam level individu. Kedua, melakukan kombinasi teknik 2SLS dengan FIXED effect untuk mengontrol un-observed factor secara simultan baik untuk level individu maupun rumah tangga. Hasil estimasi beberapa pendekatan yang berbeda tersebut dapat diperhatikan secara lebih seksama dalam Tabel 3. Kolom (1) Tabel 3 menyajikan hasil olah estimasi OLS; kolom (2) estimasi 2SLS dan kolom (3) FIXED effect.

Kolom (1) Tabel 3 mereplikasi ulang estimasi dalam Tabel 2 pada kolom (3). Dengan menggunakan pendekatan OLS, elastisitas permintaan rokok tercatat sebesar $-0,47$. Selanjutnya dalam kolom (2) di Tabel 3, disajikan hasil estimasi menggunakan pendekatan 2SLS dengan instrumental variabel besarnya cukai. Elastisitas permintaan rokok tetap negatif, namun dengan besaran yang lebih besar, yakni sebesar $-0,58$. Selanjutnya dalam kolom (3) disajikan hasil estimasi 2SLS dengan kombinasi FIXED effect pada level rumah tangga. Hasil estimasi koefisien elastisitasnya menjadi lebih tinggi secara absolut, yakni sebesar $-0,78$. Hasil estimasi ini menegaskan bahwa dengan melakukan kontrol terhadap semua faktor yang secara teori dianggap relevan, maka estimasi elasisitas permintan terhadap produk rokok di Indonesia semakin mendekati estimasi dari kajian sebelumnya di negara berkembang lain, yakni sekitar -0,5 sampai -1.

Sejauh ini estimasi pengukuran elastisitas mengasumsikan bahwa respon konsumen terhadap semua jenis rokok akan seragam. Dalam kenyataannya, terdapat beberapa tipe rokok yang beredar dipasaran. Di Indonesia terdapat beberapa jenis rokok seperti Rokok Kretek, Rokok Filter dan Rokok Putih. Berbagai tipe rokok tersebut memiliki pangsa pasar yang berbeda-beda sesuai dengan selera masing-masing konsumen. Rokok kretek, lebih banyak diminati oleh perokok usia lanjut dan dari kalangan masyarakat dengan kemampuan ekonomi menengah kebawah. Pangsa terbesar konsumen rokok di Indonesia adalah Rokok Filter dan Rokok Putih (rokok impor).

Tabel 4 menyajikan estimasi elastisitas permintaan rokok dengan memasukkan jenis rokok yang berbeda. Kolom (1) menyajikan estimasi dasar sebagaimana telah dihitung dalam tabel sebelumnya. Kolom (2) menyajikan hasil estimasi elastisitas dengan menambahkan dummy tipe rokok. Hasil estimasi menunjukkan bahwa terdapat perbedaan rata-rata konsumsi rokok yang signifikan antar tipe rokok. Selanjutnya kolom (3) menyajikan hasil estimasi elastisitas permintaan rokok dengan menambahkan variabel interaksi antara tingkat harga dengan tipe rokok. Teknik ini dilakukan untuk menangkap adanya kemungkinan perbedaan elasisitas pemintaan rokok untuk tipe yang berbeda. Hasil penelitian menunjukkan bahwa terdapat perbedaan signifikan elasititas permintaan rokok untuk jenis rokok yang berbeda. Singkatnya, respon konsumen terhadap perubahan harga sangat ditentukan oleh tipe rokok yang dikonsumsi. Dengan kata lain, respon permintaan rokok terhadap perubahan harga relatif bersifat asimetris.

\section{KESIMPULAN DAN SARAN}

Beberapa hasil kajian penting ditemukan dalam riset ini. Pertama, konsumsi rokok di Indonesia masih relatif elastis terhadap perubahan harga. Dengan melakukan kontrol yang tepat, maka elastisitas konsumsi rokok berkisar berkisar antara $-0,4$ hingga $-0,7$. Hasil ini mempertegas sinyalemen bahwa ruang bagi pemerintah untuk membatasi konsumsi rokok melalui mekanisme harga masih terbuka lebar. Penggunaan tarif cukai yang tepat akan berpotesi menahan tingkat prevalensi merokok di Indonesia yang masih sangat besar. Kedua, elastisitas rokok terhadap harga ternyata tidak seragam atau asimetris. Riset dalam paper ini menemukan bukti bahwa untuk rokok dengan tipe kretek filter, relatif lebih inelastik dibandingkan dengan rokok kretek non-mesin. Hasil simulasi secara jelas menunjukkan bahwa respon asimetris permintaan rokok terhadap cukai memiliki implikasi berupa masih relatif tingginya penerimaan negara meskipun tarif cukai dinaikkan cukup besar.

Saran kebijakan yang direkomendasikan adalah penggunaan mekanisme cukai sebagai pengendali konsumsi rokok masih dapat dilaksanakan dengan memperhatikan tipe dan jenis golongan. Dengan kata lain, perubahan tarif cukai tidak bisa dilakukan secara seragam karena baik struktur produksi maupun konsumsi rokok memiliki tipe yang khas. Rokok dengan karakteristik permintaan yang relatif inelastik (seperti rokok filter dan rokok putih) dapat lebih diprioritaskan untuk dinaikkan tarif cukainya. Sebaliknya, rokok dengan karakter permintaan 
yang elastis (rokok kretek) tidak perlu diterapkan kenaikan tarif yang sangat besar. Riset ini masih bersifat permulaan dan belum mengekspose model permintaan alternatif secara lebih komprehensif. Diharapkan, riset lanjutan akan memenuhi tuntutan pengembangan penelitian ini di masa yang akan datang.

\section{DAFTAR REFERENSI}

Chaloupka, F. J., Hu, T., Warner, K., Jakob, R., \& Yurekli, A. (2000). The Taxation of Tobacco Product. In F. Chaloupka, Tobacco Control in Developing Countries (pp. 237-272). New York: Oxford University Press.

Ekpu, V., Brown, \& K., A. (2015). The Economic Impact of Smooking and Reducing Smoking Prevalence: Review of Evidence. Tobacco Use Insight, 1-35.

Gruber, J. (2003). Smoking's Internalities. Regulation , 52-57.

Gruber, J., \& Mullainathan, S. (2002). Do Cigarette Taxes Make Smokers Happier? Cambridge: National Bureau of Economic Research.

Gujarati, D. N. (2003). Basic Econometrics. Fourth Edition. New York: McGraw Hill.

Hidayat, B., \& Thabrany, H. (2010). Cigarette Smoking in Indonesia: Examination of Myopic Model of Addictive Behaviour. International Journal of Environmental Research and Public Health, 2473-2485.

ITIC. (2013). Asia-11 Illicit Tobacco Indicator 2012. Washington DC: International Tax and Ivenstment Center.

Lockwood, B., \& Taubinsky, D. (2015). Regressive Sin Taxes. Harvard University.

Marti, J. (2011). Three Essay on The Economics of Smooking. University of Neuchatel.

MD FEB UGM. (2016). Optimalization of Excise Revenue in Indonesia. Yogyakarta: Program Magister Sains dan Doktor FEB UGM.
MD FEB UGM. (2015). Survei Pita Cukai Rokok di Kawasan FTZ dan Sekitarnya. Yogyakarta: Program Magister Sains dan Doktor FEB UGM.

O' Donoghue, T., \& Rabin, M. (2006). Optimal Sin Taxes. Journal of Public Economics , 1825-1849.

PSEKP UGM. (2014). Survei Cukai Rokok Nasional 2014. Yogyakarta: Pusat Studi Ekonomi dan Kebijakan Publik Universitas Gadjah Mada.

Scollo, M., \& Winstanley, M. (2012). Tobacco in Australia: Facts and Issues 4 Edition. Melbourne: Cancer Council Victoria.

SEATCA. (2014). ASEAN Tobacco Tax Report Card: Excecutive Summary. Bangkok: South East Asia Tobacco Control Alliance.

Wooldridge, J. M. (2009). Introductory Econometrics, A Modern Approch. Cengage Learning.

Zhao, M., Konishi, Y., \& Glewwe, P. (2010). Does Smoking Make One Dumber? Evidence from Teenagers in Rural China. University of Pennsylvania. 